\title{
Penerapan Model Pembelajaran Inquiri Terbimbing Terhadap Hasil Belajar pada Materi Hukum Newton Kelas X
}

\author{
${ }^{1}$ Resto Reswanto, ${ }^{2}$ Hadma Yuliani, ${ }^{3}$ Nur Inayah Syar \\ ${ }^{1,2)}$ Program Studi Tadris Fisika Jurusan Pendidikan MIPA FTIK IAIN Palangka Raya, Jl. \\ G.Obos Kompleks Islamic Center \\ 3) Program Studi PGMI Jurusan Tarbiyah FTIK IAIN Palangka Raya, Jl. G.Oobos \\ Kompleks Islamic Center \\ Email Korespondensi: ${ }^{1)}$ restofisika15@gmail.com; ${ }^{21}$ Hadma.yuliani@iain- \\ palangkaraya.ac.id; ${ }^{3) @ n u r . i n a y a h . s y a r @ i a i n-p a l a n g k a r a y a . a c . i d ~}$
}

\begin{tabular}{|c|c|}
\hline Article Info & Abstract \\
\hline $\begin{array}{l}\text { Article History } \\
\text { Received: O6 Januari } 2021 \\
\text { Revised: } 27 \text { June } 2021 \\
\text { Published: } 30 \text { June } 2021\end{array}$ & \multirow{2}{*}{$\begin{array}{l}\text { This study was based on the lack of student learning outcomes due to the low } \\
\text { variation in the learning model. This study aims to examine (1) Management } \\
\text { of learning using inkuiri learning model guided in newton law material class } \\
\text { X. (2) Significant influence before and after the implementation of the inkuiri } \\
\text { learning model is guided to the learning outcomes in newton law material } \\
\text { class X. This research uses quantitative approach and this type of research } \\
\text { uses Pre-Experimental design in this design there is no control group to } \\
\text { compare with the experimental group and with "One Group Pretest-Posttest } \\
\text { Design". Instruments used in the form of observation sheets of learning } \\
\text { management, tests of cognitive learning results, observation sheets affective } \\
\text { and psychomotor. The population in this study took grade X science students } \\
\text { in semester } 2 \text { at MA Muslimat NU Palangkaraya by sampling using } \\
\text { saturation sampling techniques or saturated samples then the entire } \\
\text { population was sampled. The results showed that (1) The management of } \\
\text { learning using inquiri guided with an average value of } 3.4 \text { is quite good } \\
\text { status. (2) The influence of guided inquiri learning models on learning } \\
\text { outcomes with a significant value of } 0.00<0.05 \text {. }\end{array}$} \\
\hline $\begin{array}{l}\text { Keywords } \\
\text { Guided Inquiri Lear } \\
\text { Models, Cognitive, } \\
\text { Affective, and Psych } \\
\text { Learning Outcomes }\end{array}$ & \\
\hline Informasi Art & Abstrak \\
\hline $\begin{array}{l}\text { Sejarah Artikel } \\
\text { Diterima: 06 Januari } 2021 \\
\text { Direvisi: } 27 \text { Juni } 2021 \\
\text { Dipublikasi: } 30 \text { Juni } 2021\end{array}$ & \multirow{2}{*}{$\begin{array}{l}\text { Penelitian ini bertolak dari kurangnya hasil belajar siswa dikarenakan } \\
\text { rendahnya variasi dalam model pembelajaran. Penelitian ini bertujuan untuk } \\
\text { mengkaji (1) Pengelolaan pembelajaran menggunakan model pembelajaran } \\
\text { inkuiri terbimbing pada materi hukum newton kelas X. (2) Pengaruh yang } \\
\text { signifikan sebelum dan sesudah diterapkannya model pembelajaran inkuiri } \\
\text { terbimbing terhadap hasil belajar kognitif, afektif, psikomotorik pada materi } \\
\text { hukum newton kelas X. Penelitian ini menggunakan pendekatan kuantitatif } \\
\text { dan jenis penelitian ini menggunakan rancangan Pra-Eksperimen dalam } \\
\text { rancangan ini tidak ada kelompok control untuk diperbandingkan dengan } \\
\text { kelompok eksperimen dan dengan "One Group Pretest - Posttest Design". } \\
\text { Instrumen yang digunakan berupa lembar pengamatan pengelolaan } \\
\text { pembelajaran, tes hasil belajar kognitif, lembar pengamatan afektik dan } \\
\text { psikomotorik. Populasi dalam penelitian ini mengambil siswa kelas X IPA } \\
\text { semester } 2 \text { di MA Muslimat NU Palangkaraya dengan pengambilan sampel } \\
\text { menggunakan teknik saturation sampling atau sampel jenuh maka seluruh } \\
\text { populasi dijadikan sampel. Hasil penelitian menunjukkan bahwa (1) } \\
\text { Pengelolaan pembelajaran menggunakan inquiri terbimbing dengan nilai rata } \\
\text { - rata 3,4 berstatus cukup baik. (2) Adanya pengaruh model pembelajaran } \\
\text { inquiri terbimbing terhadap hasil belajar kognitif,afektif, psikomotorik } \\
\text { dengan nilai signifikan } 0,00<0,05 \text {. }\end{array}$} \\
\hline $\begin{array}{l}\text { Kata kunci } \\
\text { Model Pembel } \\
\text { Terbimbing, H } \\
\text { Kognitif, Afek } \\
\text { Psikomotorik }\end{array}$ & \\
\hline
\end{tabular}


Sitasi: Resto, R., Yuliani, H., \& Syar, N.I. (2021). Penerapan Model Pembelajaran Inquiri Terbimbing Terhadap Hasil Belajar pada Materi Hukum Newton Kelas X. Kappa Journal. 5(1). 109-119.

\section{PENDAHULUAN}

Pendidikan sains mempunyai tujuan untuk meningkatkan kualitas peserta didik guna memenuhi kebutuhan hidupnya dalam berbagai situasi. Fisika merupakan salah satu cabang dari ilmu pengetahuan alam (IPA), yang telah berkaitan dengan cara mencari tahu tentang gejala alam secara sistematis, sehingga IPA bukan hanya penguasaan kumpulan pengetahuan yang berupa fakta-fakta, konsep-konsep, atau prinsip-prinsip saja tetapi juga merupakan suatu proses penemuan. Tujuan mempelajari fisika adalah agar dapat mengerti bagian - bagian dasar dari benda - benda dan interaksi antara benda - benda, untuk menerangkan gejala gejala alam, sehingga dalam pendidikan ini peserta didik mampu mengembangkan ataupun menerapkan pengetahuannya dalam kehidupan sehari - hari (Saroja et al, 2014).

Sekolah merupakan lembaga formal dalam kegiatan belajar mengajar, keberhasilan proses mengajar dapat dilihat dari prestasi belajar yang dicapai oleh peserta didik. Pembelajaran pada hakikatnya adalah proses interaksi antara guru dan siswa, dan lingkungan yang ada di sekitarnya, yang dalam proses tersebut terdapat upaya untuk meningkatkan kualitas diri siswa menjadi lebih baik dari sebelumnya. Semakin baik prestasi belajar maka semakin baik pula pembelajarannya. Pembelajaran akan lebih bermakna jika peserta didik mengalami sendiri apa yang dipelajarinya, terutama dalam pembelajaran fisika peserta didik tidak hanya sekedar menghafal tetapi dituntut untuk dapat membangun suatu pengetahuan dalam diri mereka sendiri dengan berperan aktif dalam proses belajar mengajar . Masalah masalah yang sering dihadapi dalam kegiatan pembelajaran antara lain pemilihan model pembelajaran yang kurang cocok, kurangnya media pembelajaran, dan kondisi kelas yang cenderung berpusat pada guru sehingga membuat peserta didik jenuh, mengantuk dan merasa pembelajaran itu terasa sulit dan membosankan (Priansa, 2017).

Berdasarkan hasil observasi yang dilakukan di MA Muslimat NU Palangkaraya bahwa sekolah tersebut sudah menggunakan kurikulum 2013. Kemudian hasil wawancara dengan guru fisika MA Muslimat NU Palangkaraya mengatakan bahwa proses pembelajaran yang digunakan di kelas masih banyak menggunakan model - model pembelajaran terdahulu yang bersifat ceramah dan berpusat pada guru, dan juga hasil belajar peserta didiknya hanya sekitar $35 \%$ - 40\% yang mencapai standar kriteria ketuntasan minimal (KKM) yang telah ditetetapkan oleh sekolah yakni 73, berdasarkan data angket yang disebar hampir semua siswa mengatakan mata pelajaran fisika adalah mata pelajaran yang susah.

Pencapaian KKM fisika peserta didik yang masih belum terpenuhi menjadi salah satu faktor rendahnya pembelajaran di kelas. Peserta didik cenderung kesulitan dalam memahami materi fisika yang disampaikan oleh guru terutama yang berkaitan dengan rumus - rumus sehingga akan mempengaruh bagaimana cara mereka menyelesaikan permasalahan dalam soal - soal . Di samping itu, faktor kejenuhan dalam pembelajaran turut mempengaruhi aktivitas belajar peserta didik di kelas. Kurangnya komunikasi antara peserta didik dan guru membuat pembelajaran tidak maksimal, kondisi pembelajaran yang seperti ini akan membuat peserta didik menjadi kurang termotivasi untuk aktif dalam pembelajaran dan akan cenderung diam dan bermain sendiri saat pembelajaran berlangsung.

Permasalahan tersebut perlu adanya solusi untuk memperbaiki hasil belajar siswa dan pengelolaan pembelajaran yang efektif agar siswa tidak merasa jenuh dalam pembelajaran 
maka diperlukan model pembelajaran yang dapat meningkatkan hasil belajar peserta didik dan menciptakan suasana menyenangkan supaya aktivitas peserta didik lebih aktif dan tidak membosankan (Hosnah, 2017). Model pembelajaran merupakan kerangka konseptual yang menggambarkan prosedur dalam mengorganisasikan pengalaman pembelajaran untuk mencapai tujuan pembelajaran (Suprihatiningrum, 2012). Salah satu model pembelajaran yang dapat meningkatkan hasil belajar dan membuat peserta didik lebih aktif yaitu model pembelajaran inkuiri terbimbing.

Model inkuiri terbimbing adalah suatu model pembelajaran inkuiri yang dalam pelaksanaannya guru menyediakan bimbingan/petunjuk yang cukup luas untuk siswa. Model pembelajaran ini melibatkan secara maksimal seluruh kemampuan peserta didik untuk mencari dan menyelidiki secara sistematis, kritis, logis, analitis, sehingga mereka dapat merumuskan sendiri penemuannya dengan penuh percaya diri. Model inkuiri terbimbing ini guru tidak melepas begitu saja kegiatan - kegiatan yang dilakukan oleh peserta didik, sehingga peserta didik yang berpikir lambat atau peserta didik yang mempunyai inteligensi rendah tetap mampu mengikuti kegiatan yang sedang dilaksanakan dan peserta didik yang mempunyai kemampuan berpikir tinggi tidak memonopoli kegiatan (A'yunin, 2016).

Kelebihan model pembelajaran inquiri terbimbing ini adalah dapat meningkatkan (1) kerja ilmiah siswa (Ariesta et al, 2011), (2) meningkatkan kemampuan berpikir logis (Purwanto et al, 2012), (3) meningkatkan berpikir kritis siswa (Puspita et al, 2013; Putri et al, 2020), (4) dapat meningkatkan kemampuan multi representasi siswa (Prahani et al, 2017), (5) dapat meningkatkan penguasaan konsep siswa (Yulianci et al, 2017), (6) aktivitas siswa (Sasmita, 2017), (7) keterampilan proses sains siswa (Ayuningtyas et al, 2017; Saputra et al, 2020), (8) meningkatkan minat dan pemahaman siswa (Isa, 2010), (9) dapat meningkatkan hasil belajar siswa (Sofiani, 2011; Hosnah, 2017). Pada penelitian ini peneliti lebih memfokuskan penelitian model pembelajaran inquiri terbimbing terhadap hasil belajar yang mencakup hasil belajar kognitif, afektif dan psikomotorik. Sehingga peneliti berharap mendapatkan hasil yang sesuai dengan teori dan penelitian terdahulu.

Salah satu konsep fisika yang dianggap cocok dengan pembelajaran inkuiri terbimbing adalah hukum newton. Siswa sangat terlibat dalam materi pembelajaran ini karena siswa dituntut untuk mengamati, menyelidiki, dan menganalisis peristiwa yang berkaitan dengan hukum newton yang ada dalam kehidupan sehari-hari terlebih lagi materi ini disampaikan oleh guru tidak melalui percobaan melainkan dengan soal - soal, sehingga pada materi ini terdapat hasil belajar yang minim (Fitasari, 2018). Maka tujuan penelitian ini adalah (1) Bagaimana pengelolaan pembelajaran menggunakan model pembelajaran inkuiri terbimbing pada materi hukum newton kelas X, dan (2) Terdapat atau tidaknya pengaruh yang signifikan sebelum dan sesudah diterapkannya model pembelajaran inkuiri terbimbing terhadap hasil belajar kognitif, afektif dan psikomotorik pada materi hukum newton kelas X.

\section{METODE}

Metode dari penelitian ini menggunakan jenis penelitian kuantitatif, dengan pendekatan pre-experiment, dengan desain penelitian yang digunakan adalah one-group pretest-posttest design. Desain ini dapat dituliskan sebagai berikut (Sukardi, 2007). 
Tabel 1. Desain Penelitian One-Group Pretest-Posttestt

\begin{tabular}{lll}
\cline { 2 - 3 } Pretest & Perlakuan & Posttest \\
\hline $\mathrm{O} 1$ & $\mathrm{X}$ & $\mathrm{O} 2$
\end{tabular}

Tabel 1 menunjukkan $\mathrm{O} 1$ adalah pretest yang dikenakan pada kelas eksperimen, O2 adalah posttest yang dikenakan pada kelas eksperimen, $X$ adalah perlakuan menggunakan model pembelajaran inquiry terbimbing. Penelitian ini dilaksanakan di MA Muslimat NU Palangka Raya pada semester genap Tahun Ajaran 2019/2020. Populasi dalam penelitian ini kelas X IPA. Pengambilan sampel pada penelitian menggunakan teknik saturation sampling atau sampel jenuh. Maka sampel yang dipilih pada penelitian ini yaitu kelas X IPA.

Teknik pengumpulan data dilakukan dengan menggunakan dekomentasi, observasi, tes hasil belajar kognitif (pretest/posttest), lembar pengamatan pengelolaan pembelajaran dan lembar pengamatan hasil belajar afektif dan psikomotorik. Tes yang digunakan berupa soal uraian yang telah diuji keabsahan datanya. Uji keabsahan data meliputi validitas, realibilitas, daya pembeda dan tingkat kesukaran. Uji gain dilakukan untuk mengetahui peningkatan hasil belajar kognitif siswa sebelum dan sesudah pembelajaran dihitung dengan rumus gain ternormalisasi.

\section{HASIL DAN PEMBAHASAN}

\section{Pengelolaan Pembelajaran Menggunakan Inquiri Terbimbing}

Pengelolaan pembelajar yang diukur hanya pada kegiatan inti dari model pembelajaran inquiri terbimbing menggunakan lembar pengamatan dengan berjumlah 6 fase yaitu: (1) Penyajian Pertanyaan/Permasalahan, (2) Membuat Hipotesis, (3) Merancang Percobaan, (4) Melakukan Percobaan Untuk Memperoleh Informasi, (5) Mengumpulkan dan Menganalisis Data, dan (6) Membuat Kesimpulan. Pengambilan data ini menggunakan 3 orang pengamat. Analisis data hasil pengelolaan pembelajaran menggunakan Microsoft Excel 2013. Berikut rekapitulasi hasil pengelolaan pembelajaran yang dapat dilihat pada tabel berikut ini :

Tabel 2. Pengelolaan Pembelajaran

\begin{tabular}{|c|c|c|}
\hline Aspek Yang Diamati & $\begin{array}{l}\text { Nilai } \\
\text { Rata - } \\
\text { rata }\end{array}$ & Kategori \\
\hline 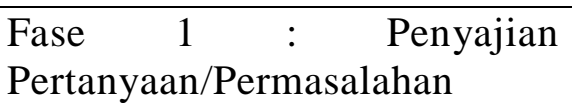 & 3,80 & Baik \\
\hline Fase $2:$ Membuat Hipotsesis & 3,15 & Cukup Baik \\
\hline Fase 3 : Merancang Percobaan & 3,60 & Baik \\
\hline $\begin{array}{lrr}\text { Fase } 4 & : & \text { Melakukan } \\
\text { Percobaan } & \text { Untuk } \\
\text { Memperoleh } & \text { Informasi }\end{array}$ & 3,50 & Baik \\
\hline $\begin{array}{l}\text { Fase } 5 \text { : Mengumpulkan } \\
\text { dan Menganalisis Data }\end{array}$ & 3,40 & Cukup Baik \\
\hline Fase $6:$ Membuat & 3,15 & Cukup Baik \\
\hline
\end{tabular}




\section{Kesimpulan}

Nilai rata - rata hasil pengelolaan pembelajaran menggunakan model pembelajaran inquiri terbimbing untuk setiap fase pada pertemuan $1-3$ ditunjukkan pada gambar dibawah ini :

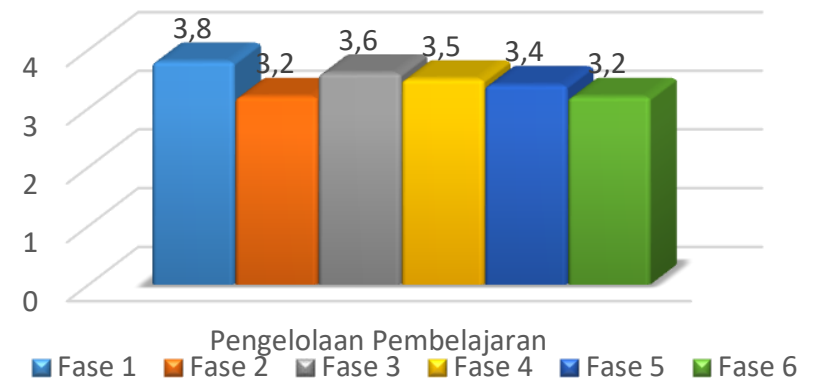

Gambar 1. Pengelolaan Pembelajaran

Pengelolaan pembelajaran ketika penelitian diamati oleh 3 orang pengamat yang dimana satu orang pengamat memegang lembar pengamatan pengelolaan beserta rubrik penilaiannya. Dalam lembar pengamatan tersebut yang diamati oleh pengamat hanya bagian kegiatan inti yang mempunyai enam fase memiliki skor maksimum. Dari Berbagi penjelasan diatas dapat disimpulkan bahwa fase yang memiliki nilai rata - rata tertinggi dapat dilihat pada gambar diatas menunjukkan nilai rata - rata pada pengelolaan pembelajaran untuk pertemuan 1-3. Nilai rata - rata tertinggi dari ke enam fase diatas yaitu pada fase 1 , fase 3 , fase 4 , fase 5 sedangkan fase 2 dan fase 6 memiliki nilai yang sama. Hasil pengelolaan pembelajaran ini bertolak belakang dengan penelitian yang dilakukan oleh Hartini (2017) karena pada penelitian yang dilakukan hartini mengalami kenaikan sedangkan pada penelitian ini mengalami turun naik hal ini dikarenakan tidak terlalu banyaknya pengamat yang dibawa pada saat pembelajaran dan juga pada saat pembelajaran guru masih tidak terlalu percaya diri dalam menjalan model pembelajaran inquiri terbimbing.

Disimpulkan bahwa pengelolaan pembelajaran menggunakan model pembelajaran inquiri terbimbing berkategori cukup baik, dan berjalan dengan lancar meskipun terdapat beberapa kendala namun tidak membuat proses belajar mengajar tidak terlaksana sama sekali hanya saja tidak maksimal dalam menjalankannya fase - fase pembelajaran mungkin dikarenakan gurunya masih kurang berpengalaman dalam menjalankan model pembelajaran inquiri terbimbing. Pengelolaan kelas merupakan keterampilan seorang guru untuk menciptakan kondisi iklim pembelajaran yang kondusif dan mengendalikan apabila terjadi gangguan dalam pembelajaran (Yamin, 2010).

\section{Hasil Belajar}

\section{a. Hasil Belajar Kognitif}

Hasil belajar kognitif siswa yang diukur menggunakan tes hasil belajar kognitif. Instrumen tes hasil belajar kognitif siswa yang digunakan berbentuk soal uraian dengan jumlah sebanyak 13 butir soal terdiri dari 4 indikator ranah kognitif. Indikator hasil belajar kognitif yang diukur diantanya yaitu: (1) Mengingat, (2) Memahami, (3) Menerapkan, dan (4) Menganalisis. Berikut Data nilai rata-rata pretest, posttest, gain, dan N-gain hasil belajar kognitif siswa yang didapat terlihat pada tabel sebagai berikut: 
Tabel 3. Nilai Rata-Rata Pretest, Posttest, Gain dan N-Gain Hasil Belajar Kognitif

\begin{tabular}{llllll}
\hline \multirow{2}{*}{ Data } & \multirow{2}{*}{$\mathrm{N}$} & \multicolumn{6}{l}{ Rata - rata } & & \\
\cline { 3 - 6 } & & Pretest & Posttest & Gain & N Gain \\
\hline Hasil Belajar Kognitif & 23 & 39,1 & 79,5 & 40,4 & 0,67 \\
\hline
\end{tabular}

\section{b. Hasil Belajar Afektif}

Hasil belajar afektif siswa yang diukur menggunakan lembar pengamatan yang dibantu oleh 3 orang pengamat. Instrumen tes hasil belajar afektif siswa yang digunakan berbentuk lembar pengamatan dengan sebanyak 4 aspek yang diamati yaitu (1) Rasa kagum, (2) Rasa ingin tahu, (3) Jujur, dan (4) Bekerja sama terdiri dari 2 indikator ranah afektif. Indikator hasil belajar afektif yang diukur diantanya yaitu: (1) Responsif, dan (2) Penilaian. Berikut rekapitulasi hasil belajar afektif siswa yang didapat terlihat pada tabel sebagai berikut:

Tabel 4. Hasil Belajar Afektif

\begin{tabular}{lll}
\hline Aspek Yang Diamati & $\begin{array}{l}\text { Nilai Rata }- \\
\text { rata }\end{array}$ & Kategori \\
\hline Rasa Kagum & 79,25 & Baik \\
\hline Rasa Ingin Tahu & 75,25 & Cukup Baik \\
\hline Jujur & 75,75 & Baik \\
\hline Bekerja Sama & 75,75 & Baik \\
\hline
\end{tabular}

\section{c. Hasil Belajar Psikomotorik}

Hasil belajar psikomotorik siswa yang diukur menggunakan lembar pengamatan yang dibantu oleh 3 orang pengamat. Instrumen tes hasil belajar psikomotorik siswa yang digunakan berbentuk lembar pengamatan dengan sebanyak 4 aspek yang diamati yaitu (1) Menyiapkan alat dan bahan percobaan untuk memecahkan masalah dalam LKS, (2) Membuat langkah percobaan berdasarkan alat dan bahan yang sudah disediakan sesuai dengan rancangan penyelesaian masalah hukum newton, (3) Mengerjakan pertanyaan LKS yang telah diberikan dengan berdiskusi bersama kelompok, dan (4) Mempresentasikan hasil pengamatan dan diskusi kelompok mengenai hukum newton terdiri dari 2 indikator ranah psikomotorik. Indikator hasil belajar psikomotorik yang diukur diantanya yaitu: (1) Manipulasi, dan (2) Ketetapan. Berikut rekapitulasi hasil belajar psikomotorik siswa yang didapat terlihat pada tabel sebagai berikut:

Tabel 5. Hasil Belajar Psikomotorik

\begin{tabular}{lll}
\hline Aspek Yang Diamati & $\begin{array}{l}\text { Nilai Rata - } \\
\text { rata }\end{array}$ & Kategori \\
\hline $\begin{array}{l}\text { Menyiapkan Alat dan Bahan } \\
\text { Percobaan Untuk Memecahkan }\end{array}$ & 77,25 & Baik \\
Masalah Dalam LKS & \\
\hline $\begin{array}{l}\text { Membuat Langkah Percobaan } \\
\text { Berdasarkan Alat Dan Bahan Yang }\end{array}$ & \\
$\begin{array}{l}\text { Sudah Disediakan Sesuai Dengan } \\
\text { Rancangan Penyelesaian Masalah }\end{array}$ & Baik \\
Hukum Newton & \\
$\begin{array}{l}\text { Mengerjakan Pertanyaan LKS } \\
\text { Yang Telah Diberikan Dengan }\end{array}$ & 75,75 \\
Berdiskusi Bersama Kelompok & Baik \\
\hline \begin{tabular}{l} 
Mempresentasikan Hasil \\
\hline
\end{tabular}
\end{tabular}




\begin{tabular}{lcc}
\hline Pengamatan & Dan & Diskusi \\
Kelompok & Mengenai & Hukum \\
Newton & & \\
\hline
\end{tabular}

\section{Uji Prasyarat Analisis}

\section{a. Uji Normalitas}

Uji normalitas pada penelitian ini untuk mengetahui distribusi atau sebaran skor data. Uji normalitas yang digunakan adalah uji Shapiro-Wilk yang dibantu program SPSS v 22.0 for Windows dengan kriteria pengujian jika signifikansi > 0,05 maka data berdistribusi normal, sedangkan jika signifikansi $<0,05$ maka data tidak berdistribusi normal. Hasil uji normalitas data untuk hasil belajar kognitif, afektif, dan psikomotorik dapat dilihat sebagai berikut:

Tabel 6. Normalitas Hasil Belajar Kognitif, Afektif, dan Psikomotorik

\begin{tabular}{llll}
\hline Data & Variabel & Sig $^{*}$ & Keterangan \\
\hline \multirow{2}{*}{ Hasil Belajar Kognitif } & Pretest & 0,642 & Normal \\
\cline { 2 - 4 } & Posttest & 0,561 & Normal \\
\hline Hasil Belajar Afektif & & 0,047 & Normal \\
\hline $\begin{array}{l}\text { Hasil Belajar } \\
\text { Psikomotorik }\end{array}$ & 0,112 & Normal \\
\hline
\end{tabular}

Tabel 6 diatas menunjukkan bahwa data pretest dan posttest diperoleh signifikansi $0,642,0,561>0,05$, dengan demikian nilai pretest dan posttest berdistribusi normal, dan data afektif dan psikomotorik diperoleh signifikansi 0,047, 0,112>0,05, dengan demikian afektif dan psikomotorik nilai berdistribusi normal.

\section{b. Uji Homogenitas}

Uji homogenitas data dikelas X IPA dilakukan dengan bantuan Versi 22.0 For Windows dengan kriteria pengujian jika signifikansi >0,05 maka data homogen, sedangkan jika signifikansi $<0,05$ maka data tidak homogen. Hasil uji homogenitas untuk data hasil belajar kognitif, afektik dan psikomotorik pada kelas X IPA dapat dilihat pada tabel berikut ini :

Tabel 7. Homogenitas Hasil Belajar Kognitif, Afektif, dan Psikomotorik

\begin{tabular}{lllll}
\hline Data & & Variabel & Sig $^{*}$ & Keterangan \\
\hline $\begin{array}{l}\text { Hasil Belajar } \\
\text { Kognitif }\end{array}$ & $\begin{array}{l}\text { Pretest } \\
\text { Posttest }\end{array}$ & 0,199 & Homogen \\
\hline $\begin{array}{l}\text { Hasil Belajar } \\
\text { Afektif dan }\end{array}$ & & 0,783 & Homogen \\
Psikomotorik & & & \\
\hline
\end{tabular}

Tabel 7 diatas menunjukkan bahwa data hasil pretest dan posttest diperoleh signifikansi 0,199>0,05, dengan demikian nilai hasil pretest dan posttest homogen dan data hasil afektif dan psikomotorik diperoleh signifikansi 0,783>0,05, dengan demikian nilai afektif dan psikomotorik hasil homogen.

\section{Uji Hipotesisis}

a. Uji Hipotesis Pengaruh Model Pembelajaran Inquiri Terbimbing Terhadap Hasil Belajar Kognitif, Afektif, dan Psikomotorik 
Setelah diperolah data hasil belajar kogitif pretest dan posttest, afektif dan psikomotorik dengan normal dan homogen. Kemudian hipotesis dapat diuji dengan menggunakan uji t yang dependent sample test untuk hasil belajar kognitif dan uji t yang one sample test untuk afektif dan psikomotorik. Adapun kriteria pengujian Jika sig.(2 failed) $<0,05$ maka Ha diterima dan Ho ditolak, sedangkan jika sig. (2 failed) $>0,05$ maka Ho dterima dan Ha ditolak. Hasil uji hipotesis hasil belajar kognitif dapat dilihat pada tabel berikut ini.

Tabel 8. Paired Sampel T Test Hasil Belajar Kognitif

\begin{tabular}{llll}
\hline \multirow{2}{*}{ Data } & \multicolumn{3}{c}{ Correlati } \\
& N & on & Sig. \\
\hline Pretest \& Posttest & 23 & .858 & .000 \\
\hline
\end{tabular}

Tabel 8 diatas menunjukkan hasil uji hipotesis hasil belajar kognitif menggunakan uji Dependent/ Paired Sample Test diperoleh nilai Sig.(2-tailed) 0,00 < 0,05 maka Ha diterima dan Ho ditolak, menunjukkan bahwa adanya pengaruh model pembelajaran Inquiri Terbimbing terhadap hasil belajar, hal ini sejalan dengan kelebihan yang dimiliki oleh model pembelajaran inquiri terbimbing yang mana model pembelajaran ini menekankan pada aspek kognitif, afektif dan psikomotorik (Sanjaya, 2006) dan bahasan ini juga sejalan dengan penelitian yang dilakukan oleh Sumarni et al (2018) dengan hasil penelitian menunjukkan bahwa ada perbedaan hasil belajar kognitif, model pembelajaran inkuiri terbimbing lebih baik dari model pembelajaran konvensional dengan persen pengaruh 29,49\%, dan penelitian yang dilakukan oleh Fitrayani (2015) dan Azizaturredha et al (2019) dengan hasil penelitian adanya pengaruh yang signifikan model pembelajaran inquiri terbimbing terhadap hasil belajar kognitif siswa SMA, Rahayu (2013) dengan hasil penelitiannya hasil belajar kognitif siswa yang diajar menggunakan model pembelajaran inkuiri terbimbing (dengan skor rata-rata 90,14) lebih baik dibandingkan dengan siswa yang diajar menggunakan model pembelajaran ceramah-praktikum (dengan skor rata-rata 88,47), Wijayanti (2010) dengan hasil penelitian pembelajaran inkuiri terbimbing dapat mengatasi kesulitan belajar siswa pada pokok bahasan cahaya yang berdampak pada peningkatan hasil belajar siswa, Irmi (2019) dengan hasil penelitian bahwa pembelajaran dengan model inkuiri berbantuan kode QR dapat meningkatkan KPS dan hasil belajar siswa, Yusakhiril (2015) dengan hasil penelitian ada pengaruh pembelajaran inkuiri terbimbing berbasis blended learning terhadap hasil belajar siswa pada materi sistem pertahanan tubuh, Savitrie (2015) dengan hasil penelitian penerapan model pembelajaran inkuiri terbimbing dapat meningkatkan hasil belajar kognitif dan KGS siswa pada materi pokok Ekosistem, dan Wulandari (2016) dengan hasil penelitian penerapan model pembelajaran inkuiri terbimbing pada pembelajaran sumber-sumber energi siswa didapatkan rata-rata hasil belajar peningkatan ketuntasan belajar sebesar $22,23 \%$.

Hal ini berarti menunjukkan memang benar bahwasanya model pembelajaran inquiri terbimbing berpengaruh terhadap hasil belajar kognitif siswa.

Hasil uji hipotesis hasil belajar afektif dapat dilihat pada tabel berikut ini.

Tabel 9. Uji One Sample Test

\begin{tabular}{llll}
\hline Data & N & $\begin{array}{l}\text { Test } \\
\text { Value }\end{array}$ & Sig. \\
\hline Hasil Belajar Afektif & 23 & 73 & .000 \\
\hline $\begin{array}{l}\text { Hasil Belajar } \\
\text { Psikomotorik }\end{array}$ & 23 & 73 & .000 \\
\hline
\end{tabular}


Tabel 9 menunjukkan hasil uji hipotesis hasil belajar afektif dan psikomotorik menggunakan uji One Sample Test diperoleh nilai Sig.(2-tailed) 0,00 < 0,05 maka Ha diterima dan Ho ditolak, menunjukkan bahwa adanya pengaruh model pembelajaran Inquiri Terbimbing terhadap hasil belajar afektif dan psikomotorik. Hal ini sejalan dengan kelebihan yang dimiliki oleh model pembelajaran inquiri terbimbing yang mana model pembelajaran ini menekankan pada aspek kognitif, afektif dan psikomotorik (Sanjaya, 2006) hasil ini juga sejalan dengan penelitian yang dilakukan oleh Pratiwi et al (2019), Zahara (2011), Ikhsan (2015). Hal ini berarti menunjukkan memang benar bahwasanya model pembelajaran inquiri terbimbing berpengaruh terhadap hasil belajar afektif dan psikomotorik siswa.

\section{KESIMPULAN}

Berdasarkan hasil analisis data dan pembahasan dapat ditarik kesimpulan bahwa pengelolaan pembelajaran menggunakan model pembelajaran inquiri terbimbing pada materi hukum newton didapat nilai rata - rata sebesar 3,15 dengan kategori cukup baik dan adanya pengaruh yang signifikan hasil belajar sebelum dan sesudah menggunakan model pembelajaran inquiri terbimbing dengan nilai signifikan $0,00<0,05$ maka Ha diterima dan Ho ditolak.

\section{SARAN}

Model Pembelajaran Inkuiri Terbimbing sangat baik diterapkan di sekolah tingkat SMP/MTs karena mampu meningkatkan hasil belajar siswa.

\section{DAFTAR PUSTAKA}

A ceyunin, Q., Indrawati, I., \& Subiki, S. 2017. Penerapan Model Inkuiri Terbimbing (Guided Inquiry) Pada Pembelajaran Fisika Materi Listrik Dinamis Di Smk. Jurnal Pembelajaran Fisika, 5(2).

Aby Saroja, Ganijanti. 2014. Seri Fisika Dasar Mekanika. Jakarta: Salemba Teknika Putri, Anisa Apriyani, Suyanto, Eko, Wicaksono,Anggit B. Pengaruh Penerapan Model Pembelajaran Inkuiri Terbimbing Dengan Praktikum Konversi Energi Panas Ke Listrik Untuk Meningkatkan Kemampuan Berpikir Kritis. Kappa Journal, 4(2).

Ariesta, R. Supartono. 2011. Pengembangan Perangkat Perkuliahan Kegiatan Laboratorium Fisika Dasar Ii Berbasis Inkuiri Terbimbing Untuk Meningkatkan Kerja Ilmiah Mahasiswa. Jurnal Pendidikan Fisika Indonesia, 7(2).

Ayuningtyas, Putri., Soegimin W.W, Z.A. Imam Supardi. 2017. Pengembangan Perangkat Pembelajaran Fisika Dengan Model Inkuiri Terbimbing Untuk Melatihkan Keterampilan Proses Sains Siswa SMA Pada Materi Fluida Statis. Jurnal Penelitian Pendidikan Sains, 4(2).

Azizaturredha, Mitha., Fatmawati, Sri., Yuliani, Hadma. 2019. Pengaruh Model Pembelajaran Inkuiri Terbimbing dengan Media Laboratorium Virtual PheT Terhadap Hasil Belajar, Keterampilan Proses Sains dan Minat Belajar Siswa Pada Pokok Bahasan Elastisitas. Edufisika: Jurnal Pendidikan Fisika 4 (01), 1-5.

Fitasari, Nurlia. Singgih Bektiarso. Subiki. 2018. Model Inquiri Terbimbing Pada Pokok Bahasan Hukum Newton Dalam Pembelajaran Fisika SMA. Seminar Nasional Pendidikan Fisika, 3.

Fitrayani, Riska. Corebima, Aloysius Duran. Ibrohim. 2015. Pengaruh Strategi Pembelajaran Problem Based Learning dan Inkuiri Terbimbing Terhadap 
Keterampilan Metakognitif, Berpikir Kritis, dan Hasil Belajar Kognitif Siswa SMA. Jurnal Pendidikan Sains, 3(4).

Hartini. 2017. Penerapan model pembelajaran inkuiri terbimbing dengan strategi REACT dan model pembelajaran inkuiri terbimbing terhadap pemahaman konsep dan keterampilan proses sains. Palangkaraya : IAIN Palangkaraya

Hosnah, WM. 2017. Pengaruh Model Pembelajaran Inquiri Terbimbing Terhadap Hasil Belajar Siswa. Jurnal Pembelajaran Fisika, 6(2).

Ikhsan, Muhamad. 2015. Pengaruh Model Pembelajaran Inkuiri Terbimbing Terhadap Hasil Belajar Ditinjau Dari Keterampilan Observasi Siswa Kelas X Sma Muhammadiyah Mataram Tahun Pelajaran 2015/2016. Jurnal Ilmiah Mandala Educations, 2(2).

Irmi I. Hasan, M. Gani, A. 2019. Penerapan Model Inkuiri Terbimbing Berbantuan Quick Response Code Untuk Meningkatkan Ketrampilan Proses Sains Dan Hasil Belajar Siswa Pada Materi Hidrolisis Garam. Jurnal Ipa \& Pembelajaran Ipa, 4(1).

Isa, A .Wahyudin, Sutikno. 2010. Keefektifan Pembelajaran Berbantuan Multimedia Menggunakan Metode Inkuiri Terbimbing Untuk Meningkatkan Minat Dan Pemahaman Siswa.Jurnal Pendidikan Fisika Indonesia, 6(1).

Prahani, Binar Kurnia. Soegimin W. W. Leny Yuanita 2017. Pengembangan Perangkat Pembelajaran Fisika Model Inkuiri Terbimbing Untuk Melatihkan Kemampuan Multi Representasi Siswa SMA. Jurnal Penelitian Pendidikan Sains, 4(2).

Pratiwi, Fitri Khana. Wijayati, Nanik. Muhatmanti, Widhi dan Marsudi. 2019. Pengaruh Model Pembelajaran Inquiri Terbimbing Berbasis Penilaian Autentik Terhadap Hasil Belajar Siswa. National Scientific Journal Of Unnes, 13 (1).

Priansa, Donni Junni, S.Pd. S.E. M.M. QWP. 2017. Pengembangan Strategi dan Model Pembelajaran. Bandung: Pustaka Setia

Purwanto , Andik .2012. Kemampuan Berpikir Logis Siswa Sma Negeri 8 Kota Bengkulu Dengan Menerapkan Model Inkuiri Terbimbing Dalam Pembelajaran Fisika. Jurnal Exacta, 10(2).

Puspita, Asri Trisna. Budi Jatmiko. 2013. Implementasi Model Pembelajaran Inkuiri Terbimbing (Guided Inquiry) Terhadap Keterampilan Berpikir Kritis Siswa Pada Pembelajaran Fisika Materi Fluida Statis Kelas Xi Di Sma Negeri 2 Sidoarjo. Jurnal Inovasi Pendidikan Fisika Vol. 02 No. 03 Tahun 2013, 121 - 125.

Rahayu, Hidya Septina. 2013. Pengaruh model pembelajaran inkuiri terbimbing terhadap hasil belajar siswa pada materi larutan elektrolit dan larutan non elektrolit kelas $X$ SMA Negeri 2 Malang. Diploma Thesis, Universitas Negeri Malang

Sanjaya, Wina. 2006. Strategi Pembelajaran Berorientasi Standar Proses Pendidikan. Jakarta: Kencana Prenada Media Gruop.

Saputra, Teguh., Yuliani, Hadma., Syar, Nur Inayah. 2020. Application of Guided Inquiry Learning Model to Science Process Skills and Habits of Mind On Business and Energy Materials. Madiun: SNPF (Seminar Nasional Pendidikan Fisika) Program Studi Pendidikan Fisika FKIP Universitas PGRI Madiun.

Sasmita, Petri Reni. 2017. Penerapan Metode Inkuiri Terbimbing Menggunakan Media KIT Fisika: Upaya Meningkatkan Aktivitas dan Hasil Belajar Fisika Siswa. Jurnal Ilmiah Pendidikan Fisika Al-Biruni, 6(1). 
Savitrie, Vidya Artha. Yolida, Berti, Marpaung, Rini Rita T. 2015. Pengaruh Inkuiri Terbimbing Terhadap Hasil Belajar Ranah Kognitif Dan Keterampilan Generik Sains. Jurnal Bioterdidik Wahana Ekspresi Ilmiah, 3(10).

Sofiani, Erlina. 2011. Materi Pembelajaran Melalui Model Inkuiri Terbimbing Efektif Untuk Meningkatkan Keterampilan Pemecahan Masalah Peserta didik Berdasarkan Beberapa Perwakilan Di Sekolah Menengah Atas. Jakarta: Universitas Islam Negeri Hidayatullah.

Sukardi,. (2007). Metodologi.Penelitian Pendidikan Kompetensi dan Praktiknya, Jakarta : PT Bumi Aksara

Sumarni, S. Santoso, Bimo Budi. Suparman, Achmad Rante. 2018. Pengaruh Model Pembelajaran Inquiri Terbimbing Terhadap Hasil Belajar Kognitif Peserta Didik. Jurnal Komunikasi Pendidikan, 1(1).

Suprihatiningrum, Jamil. 2012. Strategi Pembelajaran. Yogyakarta: A-Ruzz Media.

Wijayanti, P.I. Mosik . N, Hindarto. 2010. Eksplorasi Kesulitan Belajar Siswa Pada Pokok Bahasan Cahaya Dan Upaya Peningkatan Hasil Belajar Melalui Pembelajaran Inkuiri Terbimbing. Jurnal Pendidikan Fisika Indonesia, 6(1).

Wulandari, Fitria. 2016. Penerapan Model Pembelajaran Inkuiri Terbimbing Untuk Meningkatkan Hasil Belajar IPA Siswa Sekolah Dasar. Jurnal Pedagogia,

Yamin, Marintis. 2008. Paradigma Pendidikan Konstruktivistik. Jakarta: GP Press

Yulianci, Syahriani. Gunawan. Aris Doyan. 2017. Model Inkuiri Terbimbing Berbantuan Multimedia Interaktif Untuk Meningkatkan Penguasaan Konsep Fisika Peserta Didik. Jurnal Pendidikan Fisika dan Teknologi, 3(2).

Yusakhiril, Lukman. 2015. Pengaruh pembelajaran inkuiri terbimbing berbasis blended learning terhadap literasi sains dan hasil belajar siswa kelas XI SMA Negeri 5 Malang. Diploma Thesis, Universitas Negeri Malang.

Zahara, Laxmi. 2011. Penerapan Pembelajaran Kontekstual Model Inkuiri Terbimbing Untuk Meningkatkan Hasil Belajar Fisika Siswa. Jurnal Educatio, 6 (2). 